\title{
Effects of chelating calcium in cryopreservation extender on frozen-thawed dog semen
}

[Efeitos da quelação de cálcio no meio de criopreservação no sêmen descongelado de cão]

\section{T. Deco-Souza ${ }^{1}$, T.A.R. Paula ${ }^{2}$, G.R. Araujo ${ }^{1}$, L.C.F. Bergo ${ }^{1}$, L.R.B. Carazo ${ }^{1}$,} G.S.C. Vasconcelos ${ }^{1}$, M.C.C. Silva ${ }^{3}$

\author{
${ }^{1}$ Aluno de pós-graduação - Universidade Federal de Viçosa - UFV - Viçosa, MG \\ ${ }^{2}$ Universidade Federal de Viçosa - UFV - Viçosa, MG \\ ${ }^{3}$ Aluna de pós-graduação - Faculdade de Medicina Veterinária e Zootecnia - FAMEZ/UFMS - Campo Grande, MS
}

\begin{abstract}
We evaluated the effect of reducing free calcium in the cryopreservation medium, using the calcium chelator ethylene diamine tetracetic acid (EDTA) at $0.3 \%$ and $0.5 \%$ concentrations. Three male mixed breed dogs were subjected to semen collection by digital manipulation $(n=16)$. Each ejaculate was divided in three aliquots, and each one was diluted in TRIS-glucose-egg yolk extender with $6 \%$ glycerol and $0.5 \%$ Equex STM Paste® (TGE, control); and added with 0.3\% EDTA (EDTA 0.3) or 0.5\% EDTA (EDTA 0.5). Calcium concentration reduced in EDTA 0.3 and all the calcium ions were chelated in EDTA 0.5. The EDTA addition did not affect sperm morphology or plasma membrane integrity; however, by removing all free calcium (EDTA 0.5), the sperm motility reduced (64.7\% in TGE and $45 \%$ in EDTA $0.5 ; \mathrm{p}<0.05$ ). Acrosome integrity and sperm binding ability were not improved by calcium chelation. The failure to prevent the premature AR may explain why sperm longevity was not affected by calcium removal. Thus, the partial or complete calcium removal, through EDTA addition, is not able to prevent acrosomal damage or premature acrosomal reaction, and therefore does not improve the dog sperm binding ability.
\end{abstract}

Keywords: EDTA, sperm binding, acrosome reaction

\section{RESUMO}

Avaliou-se o efeito da redução do cálcio livre no meio de congelamento, usando-se o quelante de cálcio etilenodiaminotetracético (EDTA) a 0,3\% e 0,5\%. Três cães machos sem raça definida foram submetidos à coleta de sêmen por manipulação digital $(n=16)$. Cada ejaculado foi diluído em diluidor controle com TRIS-glicose - gema de ovo (TGE, controle), ou em diluidor TGE enriquecido com 0,3\% (EDTA 0,3) ou $0,5 \%$ de EDTA (EDTA 0,5). A concentração de cálcio reduziu no meio EDTA 0,3, e todos os íons de cálcio foram quelados no meio EDTA 0,5. A adição do EDTA e a consequente quelação do cálcio não afetaram a morfologia espermática ou a integridade da membrana plasmática, no entanto, ao remover todo o cálcio do meio (EDTA 0,5), a motilidade espermática se reduziu (64,7\% no TGE e 45\% no EDTA 0,5; P<0,05). A integridade do acrossoma e a capacidade de ligação do espermatozoide não melhoraram com a quelação do cálcio. Apesar da influência da concentração de cálcio sobre a motilidade espermática após o descongelamento, a falha em prever a reação acrossomal prematura pode explicar por que a longevidade espermática não foi afetada pela remoção do cálcio no meio. Dessa forma, a remoção parcial ou total do cálcio, por meio da adição de EDTA, não é capaz de prevenir o dano no acrossoma ou a reação acrossomal prematura e, portanto, não aumenta a capacidade do espermatozoide de se ligar ao oócito.

Palavras-chave: EDTA, ligação espermática, reação acrossomal

Recebido em 1 de agosto de 2018

Aceito em 27 de março de 2019

E-mail: thyara.araujo@ufms.br 


\section{INTRODUCTION}

Sperm cryopreservation, especially during cooling and freezing, may damage the sperm and thus reduce its viability (Hallap et al., 2006; Luvoni et al., 2003). Several studies on dog sperm cryopreservation have shown that it increases the amount of damaged or reacted acrosome (Rota et al., 1999; Chatdarong et al., 2012; Lucio et al., 2016). It is known that calcium is one of the main modulators of physiologic capacitation and acrosome reaction - AR (Breitbart, 2002; Witte and Schäfer-Somi, 2007). There are also indications that calcium influx from sperm environment and from its intracellular reservoirs also plays an important role in capacitation and acrosome reaction (AR) induced by cryopreservation (cryocapacitation and premature acrosome reaction) (Száz et al., 2000; Alhaider and Watson, 2009). In this regard, an option to reduce premature AR in cryopreserved sperm is reducing the availability of ionized calcium in the extender, which can be achieved by adding a calcium chelating substance in the freezing extender, such as ethylene diamine tetraacetic acid (EDTA).

Some studies were conducted using EDTA in cryopreservation extender in canine, goats, sheep, cattle, and bubaline sperm (Dhami and Sahni, 1993; Aisen et al., 2000; Bittencourt et al., 2004; Cunha and Lopes, 2005; Freitas et al., 2008); however, the results remain controversial. Braud et al. (2016) observed that the concentrations of $0.1 \%$ and $0.25 \%$ EDTA could reduce $(\mathrm{p}<0.05)$ the concentration of free calcium in cryopreservation extender; however, there was no difference $(\mathrm{p}>0.05)$ on sperm with intact acrosome when compared to the control (without EDTA). According to the author, the EDTA concentrations $(0.1 \%$ and $0.25 \%)$ probably did not reduce calcium concentrations below the ideal concentration in which AR occurs.

Thus, this research was conducted to assess whether a more intensive calcium chelation can increase sperm acrosomal integrity.

\section{MATERIAL AND METHODS}

Three male mixed breed dogs, aged from 2 to 5 years old, were used. The animals were maintained in $15 \mathrm{~m}^{2}$ individual boxes exposed to natural light and were fed a dry food diet and water ad libitum. All investigations were approved by the Ethics Committee for Animal Use of the Universidade Federal de Viçosa Brazil (84/2012).

Semen was collected by manual stimulation. Two of the animals were subjected to five collection procedures and one animal was subjected to six collection procedures $(\mathrm{N}=16)$ at a minimum 2-day intervals. The sperm-rich fraction of each ejaculate was collected into a calibrated tube with water-coat pre-warmed to $37^{\circ} \mathrm{C}$.

Immediately following collection, each ejaculate was evaluated for sperm forward progressive motility (SPM - on a scale from zero to five, where five represented the best SPM) and sperm motility (SM - from 0 to $100 \%$, in increments of $5 \%$ ), using a subjective analysis under a microscope (100× magnification). An aliquot of each diluted semen sample was fixed in Karnovisk fixative (Karnovsky, 1965) and later evaluated for sperm morphology (200 cells/ejaculate) under phase-contrast microscopy (1000× magnification). Individual cells were classified as normal, major defects, or minor defects in terms of their perceived adverse effects upon male fertility (Blom, 1973). The sperm concentration was assessed using a hemocytometer, and the concentration of motile sperm was determined by multiplying the sperm concentration by the sperm motility.

After evaluation, the ejaculates were diluted in maintenance extender (ME; TRIS 24g/L; citric acid $14 \mathrm{~g} / \mathrm{L}$; glucose $8 \mathrm{~g} / \mathrm{L}$; amikacin $0,2 \mathrm{~g} / \mathrm{L}$; egg yolk $200 \mathrm{~mL} / \mathrm{L}$ ) to a target concentration of $100 \times$ $10^{6}$ motile sperm $/ \mathrm{mL}$.

The membrane function was evaluated using the hypo-osmotic swelling test (HOST). An aliquot of diluted semen $(5 \mu \mathrm{L})$ was incubated in $20 \mu \mathrm{L}$ of $150 \mathrm{mOsmol} / \mathrm{kg}$ sucrose solution (Melo and Henry, 1999; Papa et al., 2008) at $38^{\circ} \mathrm{C}$ for 30 min, and then fixed in Karnovisk fixative (Karnovsky, 1965). The percentage of swollen spermatozoa was evaluated by phase-contrast microscopy (1000× magnification). One hundred cells were assessed, and those with a bent or coiled tail were considered functional. The total number of reactive spermatozoa was corrected, excluding the population with the same characteristics (spermatozoa with bent and coiled 
tail) in the sperm morphology test (Melo and Henry, 1999).

Calcium concentration was measured using a spectrophotometer (E-225D, Companhia Equipadora de Laboratórios Modernos - CELM, Brazil) at 370 nanometers wavelength using a calcium measuring kit (Cálcio, In Vitro Diagnóstica Ltda, Brazil) in fresh (diluted) semen and frozen-thawed semen for each treatment.

After evaluation, semen $\left(100 \times 10^{6}\right.$ motile sperm $/ \mathrm{mL}$ ) was divided into three aliquots. Each aliquot was diluted $(1: 1)$ in one of the cryopreservation media: TGE - $12 \%$ glycerol, $1 \%$ Equex STM Paste (Nova Chemical Sales, USA) diluted in ME; EDTA 0.3 - 12\% glycerol, 1\% Equex STM Paste; $0.6 \%$ EDTA diluted in ME; and EDTA 0.5 - 12\% glycerol, 1\% Equex STM Paste; $1.0 \%$ EDTA diluted in ME. Thus, sperm was cryopreserved at a final concentration of 50 $\mathrm{x} 10^{6}$ motile sperm $/ \mathrm{mL}, 6 \%$ glycerol, $0.5 \%$ Equex STM Paste ${ }^{\circledR}$ (TGE) and 0.3\% EDTA (EDTA 0.3) or $0.5 \%$ EDTA (EDTA 0.5).

Samples were packed in $0.25-\mathrm{mL}$ straws, placed in a glass tube that was placed in a glass bottle containing water $\left(600 \mathrm{~mL}\right.$ at $\left.38{ }^{\circ} \mathrm{C}\right)$, and transferred to a polystyrene container (12L) containing an 11-cm column of ice and water at room temperature in order to reach $4 \circ \mathrm{C}$ after 60 min. After this period, the samples were maintained in this container for another $60 \mathrm{~min}$ at $4 \circ \mathrm{C}$ (Deco-Souza et al., 2013). The straws were frozen at a rate of $-5.8 \circ \mathrm{C} / \mathrm{min}$ at $10 \mathrm{~cm}$ above the liquid nitrogen surface for $15 \mathrm{~min}$ by using a polystyrene container and then stored in liquid nitrogen.

The straws were thawed in a water bath at $38^{\circ} \mathrm{C}$ for $30 \mathrm{~s}$, where they were maintained for evaluation. Each frozen-thawed sample was assessed for forward progressive motility, sperm motility, the hypoosmotic swelling test, and sperm morphology as described for fresh semen. Frozen-thawed samples were also assessed for sperm binding ability - Sperm binding assay using hen perivitelline membrane (S-PVM assay); for plasmatic and acrosomal membrane integrities fluorescent probes; and for longevity - thermo resistance test.

The S-PVM assay was performed as described by Araujo et al. (2015). Briefly, a circular silicone device containing two rings (one with a 4-mm internal diameter and an 8-mm external diameter - RLD 1 - and another one with an 8-mm internal diameter - RLD 2) was used for keeping perivitelline membranes (PVM) stretched during the assay. Hen's PVM were isolated from the yolks of freshly laid, unfertilized hen eggs and washed with sterile TALP-HEPES (Costa, 1994) until the PVM became translucent. The membrane was then placed into a Petri dish containing modified TALP-HEPES (Costa, 1994) where the PVM was fitted over the RDL-1 and sectioned in order to fit the device. Subsequently, the RDL-2 was fitted over the RDL-1 in order to properly stretch the PVM and maintain a $12.56 \mathrm{~mm}^{2}$ fully exposed area. The membrane was placed in TCM 199 solution (Costa et al., 1997) in a multi-well culture plate and incubated for $30 \mathrm{~min}$ in a humidified atmosphere containing $5 \% \quad \mathrm{CO}_{2}$ at $38^{\circ} \mathrm{C}$ until the semen were processed.

Aliquots $(20 \mu \mathrm{L})$ of semen at $0.5 \times 10^{6} \mathrm{sperm} / \mathrm{mL}$ were placed into the well and co-incubated with the PVM in a humidified atmosphere containing $5 \% \mathrm{CO}_{2}$ at $38^{\circ} \mathrm{C}$ for $60 \mathrm{~min}$. Sperm was stained with a combination of Hoechst 33342 (H342; H1399, Molecular Probes, USA) - 200 $\mu \mathrm{L}$, $40 \mu \mathrm{g} / \mathrm{mL}$ in DPBS buffer - and propidium iodide (PI; P4170, Sigma-Aldrich Co., Germany) $20 \mu \mathrm{L}, 2 \mathrm{mg} / \mathrm{mL}$ in DPBS buffer - after 30 and 50 min of incubation, respectively. After $60 \mathrm{~min}$ of co-incubation, each well was gently rinsed four times by drop-wise addition of $1000 \mu \mathrm{L}$ of modified TALP-HEPES (Costa et al., 1997) to remove liquids and unbound sperm. The number of sperm bound per well was determined by counting fluorescent sperm nuclei in all the exposed PVM (12.56 mm2) at 400× magnification using an epifluorescence microscope (Nikon, excitation: $365 \mathrm{~nm}$; emission: $410 \mathrm{~nm})$. The results are presented as the total sperm bound to the PVM.

The plasmatic and acrosomal membrane integrities were assessed using a combination of three fluorescent probes: PI, H342 and peanut agglutinin conjugated with fluorescein isothiocyanate (FITC-PNA; L7381, SigmaAldrich Co., Germany). The fluorescent probes were stored in the dark at $5 \circ \mathrm{C}$ (FITC-PNA $1 \mathrm{mg} / \mathrm{mL}$ in DPBS) or at $-20{ }^{\circ} \mathrm{C}$ (PI $25 \mathrm{mg} / \mathrm{mL}$ in DMSO; H342 $25 \mathrm{mg} / \mathrm{mL}$ in DMSO). Semen (5 $\mu \mathrm{l})$ was incubated with $30 \mu \mathrm{l}$ of $\mathrm{H} 342(200 \mu \mathrm{g} / \mathrm{mL}$ in DPBS) and $20 \mu \mathrm{l}$ of FITC-PNA $(10 \mu \mathrm{g} / \mathrm{mL}$ in 
sodium citrate $3 \%$ diluted in DPBS) for $10 \mathrm{~min}$ at $38{ }^{\circ} \mathrm{C}$; after this period, $2 \mu \mathrm{l}$ of PI $(2 \mathrm{mg} / \mathrm{mL}$ in DPBS) was added. After $3 \mathrm{~min}$, semen was evaluated by epifluorescence microscopy with triple filter DAPI/FITC/TEXAS (Motic, Canada). A total of 200 spermatozoa per sample were examined at $1000 \times$ magnification.

The spermatozoa were classified based on the fluorescence emitted from each probe as: damaged plasma membrane and intact acrosome (DI; only the nucleus emitting red fluorescence), intact plasma membrane and intact acrosome (II; only the nucleus emitting blue fluorescence), damaged plasma membrane and damaged acrosome (DD; the nucleus emitting red fluorescence and the acrosomal region emitting green fluorescence) and intact plasma membrane and damaged acrosome (ID; the nucleus emitting blue fluorescence and the acrosome region emitting green fluorescence).

Two minutes after thawing and every $15 \mathrm{~min}$ (total of $60 \mathrm{~min}$ ) the semen was evaluated for SM as described previously.

Differences between the three treatments were analyzed with Duncan test or Kruskal Wallis test, depending on the distribution of the data. Differences between sperm forward progressive motility were analyzed with Kruskal Wallis test. All data are presented as mean \pm S.D. $P$ values $\leq 0.05$ were considered significant.

\section{RESULTS}

We used only ejaculates with $\mathrm{SM} \geq 70 \%, \mathrm{SPM} \geq 3$ and concentration $\geq 150 \times 10^{6}$ motile sperm $/ \mathrm{mL}$ (Manual..., 2013) (Table 1).

The calcium concentration in fresh semen diluted in ME $\left(100 \times 10^{6}\right.$ sperm $\left./ \mathrm{mL}\right)$ was $23 \mathrm{mg} / \mathrm{dL}$. Both EDTA concentrations could reduce calcium concentration, but when EDTA was added to a final concentration of $0.5 \%$, all the calcium ions were chelated (Table 2); thus, there was no free calcium in the cryopreservation extender. However, only SM differed $(\mathrm{p}<0.05)$ between the three treatments (TGE, EDTA 0.3 and EDTA 0.5) and the SPM differed between EDTA 0.3 and EDTA 0.5 (Table 2).

There was no difference in SM after 60min incubation between the three treatments (Table 3). Thus, sperm longevity, assessed by the TRT, was not affected by the EDTA concentration.

Table 1. Motility, morphology, and membrane integrity of fresh dog sperm $(n=3 ; N=16)$

\begin{tabular}{lc}
\hline Sperm characteristics & Fresh semen \\
\hline Forward progressive motility & $4.3 \pm 0.5$ \\
Sperm motility (\%) & $85.3 \pm 7.4$ \\
Membrane Integrity (\%) & $68.0 \pm 21.1$ \\
Total abnormalities (\%) & $33.3 \pm 22.6$ \\
Major defects (\%) & $8.5 \pm 9.4$ \\
Minor defects (\%) & $24.8 \pm 17.9$ \\
\hline
\end{tabular}

Data presented Means \pm S.D

Table 2. Motility, morphology, membrane integrity and sperm binding ability of frozen-thawed dog sperm, cryopreserved with $(0.3 \%$ - EDTA $0.3 ; 0.5 \%$ - EDTA 0.5$)$ or without (TGE) EDTA $(n=3 ; \mathrm{N}=16)$

\begin{tabular}{lccc} 
& TGE & EDTA 0.3 & EDTA0.5 \\
\hline Ca (mg/dL)** & $22.7 \pm 3.1^{\mathrm{a}}$ & $1.5 \pm 1.3^{\mathrm{b}}$ & $0.00 \pm 0.00^{\mathrm{c}}$ \\
Forward progressive motility* & $3.0 \pm 0.5^{\mathrm{bc}}$ & $3.1 \pm 0.4^{\mathrm{b}}$ & $2.4 \pm 0.6^{\mathrm{c}}$ \\
Sperm motility (\%)* & $64.7 \pm 14.2^{\mathrm{b}}$ & $62.8 \pm 19.2^{\mathrm{b}}$ & $45.0 \pm 20.6^{\mathrm{c}}$ \\
Membrane Integrity (\%)** & $42.7 \pm 19.8^{\mathrm{a}}$ & $49.6 \pm 19.8^{\mathrm{a}}$ & $46.5 \pm 21.1^{\mathrm{a}}$ \\
Total pathologies (\%)** & $59.6 \pm 18.2^{\mathrm{a}}$ & $49.8 \pm 23.0^{\mathrm{a}}$ & $50.4 \pm 20.2^{\mathrm{a}}$ \\
Major defects $(\%)^{* *}$ & $31.1 \pm 17.0^{\mathrm{a}}$ & $22.3 \pm 17.6^{\mathrm{a}}$ & $26.4 \pm 19.8^{\mathrm{a}}$ \\
Minor defects $(\%)^{* *}$ & $28.50 \pm 8.5^{\mathrm{a}}$ & $27.4 \pm 15.3^{\mathrm{a}}$ & $23.9 \pm 10.0^{\mathrm{a}}$ \\
DI $(\%)^{* *}$ & $45.0 \pm 13.9^{\mathrm{a}}$ & $52.1 \pm 21.3^{\mathrm{a}}$ & $49.7 \pm 24.6^{\mathrm{a}}$ \\
II $(\%)^{* *}$ & $14.0 \pm 11.4^{\mathrm{a}}$ & $10.8 \pm 9.6^{\mathrm{a}}$ & $14.0 \pm 13.9^{\mathrm{a}}$ \\
DD $(\%)^{* *}$ & $40.7 \pm 10.6^{\mathrm{a}}$ & $36.9 \pm 16.1^{\mathrm{a}}$ & $36.3 \pm 21.3^{\mathrm{a}}$ \\
ID $(\%)^{* *}$ & $0.3 \pm 0.6^{\mathrm{a}}$ & $0.3 \pm 0.6^{\mathrm{a}}$ & $0.00 \pm 0.00^{\mathrm{a}}$ \\
Sperm binding ability** & $57.0 \pm 39.9^{\mathrm{a}}$ & $51.7 \pm 48.9^{\mathrm{a}}$ & $41.9 \pm 37.6^{\mathrm{a}}$ \\
\hline
\end{tabular}

Means \pm S.D. Mean values within columns with different letters differ significantly $(p<0.05)$. DI: damaged plasma membrane and intact acrosome; II: intact plasma membrane and intact acrosome; DD: damaged plasma membrane and damaged acrosome; ID: intact plasma membrane and damaged acrosome. ${ }^{*}$ Kruskal-Wallis test **Ducan Test. Table 3. Longevity of frozen-thawed dog sperm, cryopreserved with (0.3\% - EDTA 0.3; $0.5 \%$ - EDTA 0.5) or without (TGE) EDTA $(n=3 ; N=16)$. 


\begin{tabular}{cccc}
\hline & \multicolumn{3}{c}{ Sperm motility (\%) } \\
Time (minutes) & TGE & EDTA 0.3 & EDTA0.5 \\
\hline 0 & $64.7 \pm 14.2^{\mathrm{a}}$ & $62.8 \pm 19.2^{\mathrm{a}}$ & $45.0 \pm 20.6^{\mathrm{b}}$ \\
15 & $49.2 \pm 17.3^{\mathrm{a}}$ & $47.2 \pm 21.4^{\mathrm{a}}$ & $28.1 \pm 20.5^{\mathrm{a}}$ \\
30 & $33.3 \pm 18.1^{\mathrm{a}}$ & $34.7 \pm 24.0^{\mathrm{a}}$ & $21.1 \pm 20.3^{\mathrm{a}}$ \\
65 & $20.6 \pm 21.2^{\mathrm{a}}$ & $19.4 \pm 18.2^{\mathrm{a}}$ & $11.1 \pm 15.7^{\mathrm{a}}$ \\
\hline 0 & $11.4 \pm 13.7^{\mathrm{a}}$ & $13.9 \pm 17.5^{\mathrm{a}}$ & $5.0 \pm 12.0^{\mathrm{a}}$ \\
\hline
\end{tabular}

Means \pm S.D. Mean values within columns with different letters differ significantly (p < 0.05$)$ - Duncan Test.

\section{DISCUSSION}

EDTA can incorporate calcium ion through divalent bonds from the oxygen present in its structure, thus enclosing the calcium ion in a heterocyclic chain and chelating it. We used EDTA to chelate free calcium in maintenance and freezing extender, making it unavailable to sperm. Under physiological conditions, after binding to zona pellucida, the sperm undergoes AR releasing the enzymes necessary for sperm penetration (Breitbart, 2002; Costa et al., 2010; Witte and Schäfer-Somi, 2007). This process depends on the mobilization of extra and intracellular calcium reservoirs (Hewitt and England, 1998; Alhaider and Watson, 2009; Száz et al., 2000). It is known that the cooling and the freezing processes promotes changes in the sperm's ability to regulate the inflow and outflow of calcium ions (Bailey et al., 2000; Száz et al., 2000). Thus, although the mechanism is not well understood, the cryopreservation process stimulates sperm capacitation (cryocapacitation) and facilitates the occurrence of the AR (premature AR) (Cormier and Bailey, 2003). The cryopreservation diluents containing TRIS, citrate and egg yolk are widely used in the freezing of dog semen (Santana et al., 2013; Lucio et al., 2016); however, Braud et al. (2016) observed that calcium concentration in this extender is about 10 times higher than in the ejaculate. Thus, we can presume that by chelating calcium in cryopreservation extender, the premature AR may reduce (Mahi and Yanagimachi, 1978). However, this was not observed in this study.

Both EDTA concentrations $(0.3 \%$ and $0.5 \%)$ could reduce $(\mathrm{p}<0.05)$ free calcium concentration, although all the calcium ions were chelated only when EDTA was added to a final concentration of $0.5 \%$ (Table 2).

There was no difference $(\mathrm{p}>0.05)$ in sperm reacted in the HOST between the three treatments (Table $3)$. The HOST challenges the sperm plasmatic membrane (PM) in a low osmolarity extender, evaluating its ability to maintain the osmotic balance between intra and extracellular environments. In this respect, EDTA addition and the consequent reduction (EDTA 0.3) or absence (EDTA 0.5) of free calcium does not affect dog sperm plasma membrane function.

Likewise, there was no difference $(p>0.05)$ on total pathologies between the three treatments. Therefore, we can conclude that EDTA did not promoted morphological changes in dog sperm, even when it was used in higher concentrations than tested in other species and in dog. Bittencourt et al. (2004) assessed the effect of EDTA (0.1\%) in freezing extender for goat semen cryopreservation and found an increase in the amount of major defects compared to extender without EDTA. However, this difference was not detected in another study with the same species (Freitas et al., 2008). Braud et al. (2016) found no difference in pathologies when EDTA was added in the extender $(0.1 \%$ and $0.3 \%)$ for dog semen cryopreservation.

In this experiment, the reduction (0.3 EDTA) and the removal (EDTA 0.5) of free calcium could not increase the percentage of thawed dog sperm with intact acrosome (II and DI; $>>0.05$ ). There were also no differences in the sperm binding ability according to the S-PVM assay. It has been shown that calcium in the extender reduces sperm viability and affects acrosome morphology (Bailey and Buhr, 1995). However, corroborating our results, other researchers also did not find an increase in acrosome integrity (not reacted) in thawed sperm when they used EDTA in extender (Aisen et al., 2000; Freitas et al., 2008; Braud et al., 2016). Thus, the reduction or removal of free calcium in the extender does not prevent the cryocapacitation and does not improve sperm binding ability in dog sperm. Possibly, the amount of intracellular calcium is sufficient to trigger this reaction. 
As shown in Table 2, there was no difference $(p>0.05)$ in SM between TGE and EDTA 0.3 groups; however, it was lower in EDTA 0.5, in which the calcium was completely removed. This may be expected as calcium is necessary for sperm motility and in the EDTA 0.5 the calcium was completely removed (Lee et al., 1996). Thus, experimentations should evaluate if post thaw calcium addition can revert the effects of calcium removal during cryopreservation.

Besides the difference in SM immediately after thawing, there was no difference $(p>0.05)$ in sperm longevity after $60 \mathrm{~min}$ incubation (Table 3 ). After capacitation (and acrosome reaction), sperm has limited ability to react to osmotic stress and changes its motility, which reduces the longevity (Flesch and Gadella, 2000). Besides the interference of calcium concentration on SM after thawing, the failure to prevent the premature AR may explain why sperm longevity was not affected by calcium removal.

Some studies were conducted to evaluate EDTA addition for mammal sperm cryopreservation. Aisen et al. (2000) had higher percentages of ram sperm with intact acrosome and better sperm motility, but this condition was observed only when EDTA was used with the disaccharide trehalose. Bittencourt et al. (2004) observed an increase in sperm motility in frozen-thawed goat semen, frozen with EDTA; however, it was not observed in another study with the same species (Freitas et al., 2008). The divergence found in the literature regarding the effect of calcium chelation in freezing extender is related to the different extender compositions and cryopreservation processing, which affect the sperm in different ways. Moreover, those studies did not measure calcium concentration after addition of the chelating agent; thus, it cannot be determined if the harmful or beneficial effects found were actually due to the change in calcium concentration. These differences also demonstrate that calcium removal is not always desirable for the sperm. In fact, the absence of this ion is deleterious, since calcium is essential for sperm movement.

\section{CONCLUSION}

We conclude that partial or total calcium removal through the addition of a chelating agent (EDTA) does not prevent acrosomal membrane damage or premature AR and thus does not improve sperm longevity and binding ability. There are probably different factors in diluents and cryopreservation protocols, rather than calcium concentration, which favor cryocapacitation and premature AR in this protocol.

\section{FUNDING}

This work was supported by the Conselho Nacional de Desenvolvimento Científico e Tecnológico (National Council for Scientific and Technological Development) - Brazil (grant number 485600/2011-0) and the Fundação de Amparo à Pesquisa do Estado de Minas Gerais (Foundation for Research Support of Minas Gerais) - Brazil (grant number PPM-00164-11). This study was financed in part by the Fundação Universidade Federal de Mato Grosso do Sul UFMS/MEC - Brazil.

\section{ACKNOWLEDGMENTS}

The authors would like to thank to Coordenação de Aperfeiçoamento de Pessoal de Nível Superior - CAPES (Coordination for the Improvement of Personnel in Higher Education) and Fundação de Amparo à Pesquisa do Estado de Minas Gerais (Foundation for Research Support of Minas Gerais) for providing scholarship.

\section{REFERENCES}

AISEN, E.G.; ALVAREZ, H.L.; VENTURINO, A.; GARDE, J.J. Effect of trehalose and EDTA on cryoprotective action of ram semen diluents. Theriogenology, v.53, p.1053-1061, 2000.

ALHAIDER, A.K.; WATSON, P.F. Cryopreservation of dog semen: the effects of Equex STM paste on plasma membrane fluidity and the control of intracellular free calcium. Anim. Reprod. Sci., v.110, p.147-161, 2009.

ARAUJO, G.R.; PAULA, T.A.R.; DECOSOUZA, T.; GARAY, R.M. Ocelot and oncilla spermatozoa can bind hen egg perivitelline membranes. Anim. Reprod. Sci., v.163, p.56-62, 2015. 
BAILEY, J.L.; BILODEAU, J.F.; CORMIER, N. Semen cryopreservation in domestic animals: a damaging and capacitating phenomenon. $J$. Androl., v.21, p.1-7, 2000. BAILEY, J.L.; BUHR, M.M. Regulation of internal $\mathrm{Ca} 2+$ by chilled bull and boar spermatozoa. Cryobiology, v.32, p.259$269,1995$.

BITTENCOURT, R.F.; RIBEIRO, A.L.; SANTOS, A.D.F.; FURST, R. et al. Utilização de glicerol e etilenoglicol como crioprotetores na congelação do sêmen caprino. Ciênc. Anim. Bras., v.5, p.27-32, 2004.

BLOM, E. The ultrastructure of some characteristic sperm defects and a proposal for a new classification of the bull spermiogram. Nord. Vet. Med., v.25, p.383-391, 1973.

BRAUD, C.; BERGO, L.C.F.; ARAÚJO, G.R.; DECO-SOUZA, T. et al. Role of EDTA as a chelating agent in canine semen cryopreservation. Anim. Reprod. Sci., v.169, p.122-123, 2016.

BREITBART, H. Intracellular calcium regulation in sperm capacitation and acrosomal reaction. Mol. Cell. Endocrinol., v.187, p.139-144, 2002.

CHATDARONG, K.; CHAIVECHAKARN, A.; THUWANUT, P.; PONGLOWHAPAN, S. Effects of cold storage prior to freezing on superoxide dismutase, glutathione peroxidase activities, level of total reactive oxygen species and sperm quality in dogs. Reprod. Domest. Anim., v.47, p.274-277, 2012.

CORMIER, N.; BAILEY, J.L. A differential mechanism is involved during heparin- and cryopreservation-induced capacitation. Biol. Reprod., p.69, v.177-185, 2003.

COSTA, E.P. Aspectos morfológicos (citológicos e ultraestruturais) e desenvolvimento de ovócitos bovinos in vitro. 1994. $155 \mathrm{f}$. Tese (Doutorado) Escola de Veterinária, Universidade Federal de Minas Gerais, Belo Horizonte, MG.

COSTA, E.P.; VALE FILHO, V.R.; NOGUEIRA, J.C.; SA, W.F., COSTA; A.H.A. Técnica simplificada para o desnudamento rápido de ovócitos de bovinos. Arq. Bras. Med. Vet. Zootec., v.49, p.425-432, 1997.

COSTA, M.Z.; OLIVEIRA, L.Z.; RESENDE, M.V.; LUCIO, A.C. et al. Induction of the acrosome reaction test to in vitro estimate embryo production in Nelore cattle. Arq. Bras. Med. Vet. Zootec., v.62, p.771-777, 2010.
CUNHA, I.C.N.; LOPES, M.D. Efeito de três diferentes diluidores sobre o sêmen canino submetido a dois protocolos de descongelamento. Braz. J. Vet. Res. Anim. Sci., v.42, p.372-380, 2005.

DECO-SOUZA, T.; PAULA, T.A.R.; COSTA, D.S.; COSTA, E.P. Comparação entre duas concentrações de glicerol para a criopreservação de sêmen de suçuarana (Puma concolor ). Pesqui. Vet. Bras., v.33, p.512-516, 2013.

DHAMI, A.; SAHNI, K. Effect of extenders, additives and deep freezing on the leakage of lactic dehydrogenase from cattle and buffalo spermatozoa. Indian J. Anim. Sci., v.63, p.251256, 1993.

FLESCH, F.M.; GADELLA, B.M. Dynamics of the mammalian sperm plasma membrane in the process of fertilization. Biochim. Biophys. Acta, v.1469, p.197-235, 2000.

FREITAS, R.; COELHO, M.C.; GONZALEZ, S.G.; FREITAS, M. Efeito de um quelante de cálcio, um detergente e da lecitina de soja sobre a qualidade do sêmen caprino congeladodescongelado. Braz. J. Vet. Res. Anim. Sci., v.45, p.305-312, 2008.

HALLAP, T.; NAGY, S.; JAAKMA, U.; JOHANNISSON, A. et al. Usefulness of a triple fluorochrome combination Merocyanine 540/YoPro 1/Hoechst 33342 in assessing membrane stability of viable frozen-thawed spermatozoa from Estonian Holstein AI bulls. Theriogenology, v.65, p.1122-1136, 2006.

HEWITT, D.A.; ENGLAND, G.C.W. An investigation of capacitation and the acrosome reaction in dog spermatozoa using a dual fluorescent staining technique. Anim. Reprod. Sci., v.51, p.321-332, 1998.

KARNOVSKY, M.J. A formaldehyde glutaraldehyde fixative of high osmolality for use in eletron microscopy. J. Cell Biol., v.27, p.137138, 1965.

LEE, C.H.; ANDERSON, M.; CHIEN, Y.W. Characterization of in-vitro spermicidal activity of chelating agent against human sperm. $J$. Pharm. Sci., v.85, p.649-654, 1996. 
LUCIO, C.F.; REGAZZI, F.M.; SILVA, L.C.G.; ANGRIMANI, D.S.R. et al. Oxidative stress at different stages of two-step semen cryopreservation procedures in dogs. Theriogenology, v.85, p.1568-1575, 2016.

LUVONI, G.C.; KALCHSCHMIDT, E.; LEONI, S.; RUGGIERO, C. Conservation of feline semen Part I: Cooling and freezing protocols. J. Feline Med. Surg., v.5, p.203-208, 2003.

MAHI, C.A.; YANAGIMACHI, R. Capacitation, acrosome reaction, and egg penetration by canine spermatozoa in a simple defined medium. Gamete Res., v.1, p.101-109, 1978.

MANUAL para exame andrológico e avaliação de sêmen animal, 3.ed. Belo Horizonte: CBRA, 2013. 52p.

MELO, M.I.V.; HENRY, M. Teste hiposmótico na avaliação do sêmen eqüino. Arq. Bras. Med. Vet. Zootec., v.51, p.71-78, 1999.

PAPA, F.O.; MELO, C.M.; FIORATTI, E.G.; DELL'AQUA, J.A. et al. Freezing of stallion epididymal sperm. Anim. Reprod. Sci., v.107, p.293-301, 2008.
ROTA, A.; PEÑA, A.I.; LINDE-FORSBERG, C.; RODRIGUEZ-MARTINEZ, H. In vitro capacitation of fresh, chilled and frozen-thawed dog spermatozoa assessed by the chlortetracycline assay and changes in motility patterns. Anim. Reprod. Sci., v.57, p.199-215, 1999.

SANTANA, M.; BATISTA, M.; ALAMO, D.; GONZÁLEZ, F. et al. Influence of Cool Storage before Freezing on the quality of frozen - thawed semen samples in dogs. Reprod. Domest. Anim., v.48, p.165-170, 2013.

SZÁZ, F.; SIRIVAIDYAPONG，S.; CHENG, F.P.; VOORHOUT, W.F. et al. Detection of calcium ionophore induced membrane changes in dog sperm as a simple method to predict the cryopreservability of dog semen. Mol. Reprod. Dev., v.55, p.289-298, 2000.

WITTE, T.S.; SCHÄFER-SOMI, S. Involvement of cholesterol, calcium and progesterone in the induction of capacitation and acrosome reaction of mammalian spermatozoa. Anim. Reprod. Sci., v.102, p.181-193, 2007. 